Formatif: Jurnal Ilmiah Pendidikan MIPA

Vol. 8, No. 3, Desember 2018, pp. 233-250

p-ISSN: 2088-351X

e-ISSN: 2502-5457

DOI: http://dx.doi.org/10.30998/formatif.v8i3.2613

\title{
Development of Sparkol Video Scribe Assisted Learning Media
}

\author{
Pengembangan Media Pembelajaran Berbantuan Sparkol Video Scribe
}

\author{
Fitri Nurrohmah (*) \\ Universitas Islam Negeri Raden Intan, Lampung \\ Fredi Ganda Putra \\ Universitas Islam Negeri Raden Intan, Lampung \\ Farida \\ Universitas Islam Negeri Raden Intan, Lampung
}

\begin{abstract}
Received: July 3, 2018
Abstract

Revised: August 17, 2018

This study aims at how to develop sparkol video scribe assisted

Accepted: September 26, 2018 responsive media. To achieve this goal the authors develop the media using research development methods with steps: (1) analysis, (2) design, (3) development, (4) implementation, (5) evaluation. Subjects in this study were students of the University of Islam Raden Intan Lampung with data collection instruments used in the form of a questionnaire given to the material experts, media experts, and questionnaire responses to students to know the interest of learning media developed mathematics. The results of this study produce a product in the form of sparkol video scribe-assisted mathematics learning media on assignment material (linear program) in higher education; knowing the feasibility of the developed product quality is very feasible with a score of 3,37 based on expert material judgment and 3,56 by the media expert in a very feasible category. Students' responses in sparkol video scribe assisted instructional media on assignment material (linear program) obtained a score of 3,55 with very interesting criteria in college. based on the suggestions from material experts and media experts to the author to be disseminated to lecturers for use in the learning process.
\end{abstract}

Keywords: Development of mathematics learning media, Sparkol Video Scribe, Linear Program, College

(*) Corresponding Author: $\quad$ fitrinurrohmah30@gmail.com

How to Cite: Nurrohmah, F. \& Putra, F. G., \& Farida, F. (2018). Development of sparkol video scribe assisted learning media. Formatif: Jurnal Ilmiah Pendidikan MIPA, 8 (3): 233-250. http://dx.doi.org/10.30998/formatif.v8i3.2613

\section{PENDAHULUAN}

Pendidikan merupakan segala situasi hidup yang mempengaruhi pertumbuhan individu sebagai pengalaman belajar yang berlangsung dalam segala lingkungan dan sepanjang hayat (Leonard \& Chaidir, 2018). Ilmu matematika adalah suatu ilmu yang keberdayaannya sudah disusun dari satu sistem yang penuh dengan perjanjian dan terbangun atas logika dari sekelompok unsur, relasi, dan operasi serta kebenarannya harus terjamin (Harini \& Oka, n.d.). Definisi lain menyatakan bahwa matematika merupakan cabang ilmu pengetahuan eksakta yang harus memiliki penalaran logis dan berhubungan 
Formatif: Jurnal Ilmiah Pendidikan MIPA

Vol. 8, No. 3, Desember 2018, pp. 233-250

p-ISSN: 2088-351X

e-ISSN: $2502-5457$

DOI: http://dx.doi.org/10.30998/formatif.v8i3.2613

dengan bilangan (Indiyani \& Listiara, 2006) dan merupakan salah satu mata pelajaran yang diterapkan di berbagai tingkat pendidikan, mulai dari SD, SMP, SMA, bahkan sampai perguruan tinggi (Layn, 2018).

Kebanyakan siswa menganggap matematika adalah mata pelajaran yang sulit dibandingkan mata pelajaran lainnya. Hal ini disebabkan karena materinya terdiri dari konsep-konsep yang terstruktur rapi, seperti rumus-rumus. Mempelajari matematika tak hanya dalam memahami konsep atau prosedurnya, tetapi banyak hal yang muncul dari proses pembelajaran matematika (Nugroho, Putra, Putra, \& Syazali, 2017).

Berdasarkan analisis kebutuhan yang dilakukan di Universitas Islam Negeri Raden Intan Lampung yang dilakukan peneliti kepada Mahasiswa Pendidikan Matematika di UIN Raden Intan Lampung dengan memberikan kuesioner kepada 16 mahasiswa terkait mata kuliah program linear (proglin), terlihat bahwa rata-rata penilaian mahasiswa berada di antara $2,51<\bar{x} \leq 3,26$. Skor yang diperoleh yaitu 31,2 dengan kriteria baik, hal tersebut dikarenakan banyak mahasiswa tidak menyukai pembelajaran yang berpacu pada buku dan dosen. Selain itu belum adanya media yang digunakan untuk membantu mahasiswa dalam proses pembelajaran yang mandiri dan terlihat banyaknya siswa yang ingin adanya pembaharuan dalam proses pembelajaran. Mereka tertarik apabila media pembelajaran yang akan digunakan berbentuk software seperti video. Karena proses pembelajaran masih menggunakan metode konvensional, hal ini berdampak pada proses pembelajaran di kelas, di mana mahasiswa cenderung bergantung pada penjelasan dosen. Hal tersebut sesuai dengan hasil wawancara dengan dosen yang mengampu mata kuliah proglin menjelaskan bahwa sistem pembelajaran yang digunakan saat ini masih menggunakan pembelajaran yang berpusat pada dosen dan buku sehingga belum memperoleh hasil yang memuaskan.

Analisis kebutuhan dilakukan peneliti dengan wawancara kepada dosen yang mengampu mata kuliah proglin tersebut. Responden mengatakan bahwa pada pembelajaran proglin tersebut belum digunakan media pembelajaran berbentuk software video sebagai media pembelajaran untuk sarana penyampaian materi yang akan membuat siswa belajar mandiri. Berdasarkan permasalahan yang ada di UIN Raden Intan Lampung, khususnya hasil pembelajaran matematika pada materi proglin, perlu diadakan terobosan-terobosan baru. Seperti adanya pembaruan dari media pembelajaran yang digunakan seorang dosen untuk membuat mahasiswa lebih tertarik dalam proses pembelajaran. Selain itu, dengan adanya media pembelajaran berbentuk software video tertentu yang bertujuan agar selama proses pembelajaran mahasiswa belajar secara mandiri dengan menggunakan media berbentuk software video.

Berdasarkan analisis kebutuhan dan analisis karakteristik siswa, maka peneliti akan mengembangkan media pembelajaran berbatuan Sparkol Video Scribe pada materi penugasan (program linear). Video tersebut dibuat untuk mengatasi permasalahan yang ada dan bertujuan untuk meminimalisasi asumsi-asumsi mahasiswa. Selain itu, agar mahasiswa dapat belajar secara mandiri. Dengan adanya media pembelajaran berbasis video tersebut, menggunakan aplikasi Sparkol Video Scribe, diharapkan penyajian atau penampilan dapat lebih menarik dan menyenangkan untuk digunakan oleh mahasiswa.

Hamalik (Arsyad, 2016) mengatakan bahwa pamakaian media pembelajaran dalam proses belajar mengajar dapat membangkitkan keinginan dan minat yang baru, membangkitkan motivasi, rangsangan kegiatan belajar, dan membawa pengaruhpengaruh biologis pada siswa. Penggunaan media pembelajaran dalam tahap orientasi pembelajaran akan sangat membantu proses keefektifan proses pembelajaran dan penyampaian pesan dan isi pelajaran pada saat itu. selain membangkitkan motivasi dan minat siswa, media pembelajaran juga dapat membantu siswa dalam meningkatkan pemahaman, menyajikan data dengan menarik dan terpercaya, memudahkan menafsirkan 
Formatif: Jurnal Ilmiah Pendidikan MIPA

Vol. 8, No. 3, Desember 2018, pp. 233-250

p-ISSN: 2088-351X

e-ISSN: 2502-5457

DOI: http://dx.doi.org/10.30998/formatif.v8i3.2613

data, dan memadatkan informasi. Diperkuat pendapat Priambodo, Awaludin, dkk. (2017) yang menyatakan bahwa dengan mengombinasikan kebermanfaatan matematika serta perkembangan ilmu pengetahuan dan teknologi, maka perlu disusun sebuah model pengajaran matematika berbantuan teknologi komputer dan pemanfaatan multimedia interaktif. Harapannya dengan bantuan komputer, hambatan-hambatan dan kesulitankesulitan yang ada dapat dieliminasi sedikit demi sedikit dan dapat memunculkan potensipotensi siswa secara maksimal.

Perkembangan teknologi yang semakin maju menuntut guru untuk mengikuti perkembangan teknologi dalam proses belajar dan mengajar (Sari, 2017). Acapkali kata media dapat diartikan sebagai alat bantu atau media komunikasi yang berfungsi untuk menyampaikan pesan pembelajaran (Setyono, Karmin, \& Wahyuningsih, 2013). Dalam kegiatan pembelajaran, media merupakan salah satu sumber belajar yang dapat menyampaikan pesan-pesan pendidikan kepada para peserta didik (Farida, 2015). Oleh karena itu peneliti tertarik untuk mengembangkan salah satu jenis media yang dikemas menggunakan program aplikasi dalam bentuk Sparkol Video Scribe.

\section{METODE}

Prosedur pengembangan yang digunakan dalam penelitian ini adalah model penelitian ADDIE. Fungsi dari model ADDIE adalah menjadi pedoman dalam membangun perangkat dan infrastruktur program pembelajaran yang efektif, dinamis, dan mendukung kinerja pembelajaran itu sendiri. Model ini terdiri dari lima tahapan, yaitu analysis, design, development or production, implementation or delivery, and evaluation yang disajikan dalam gambar 1.

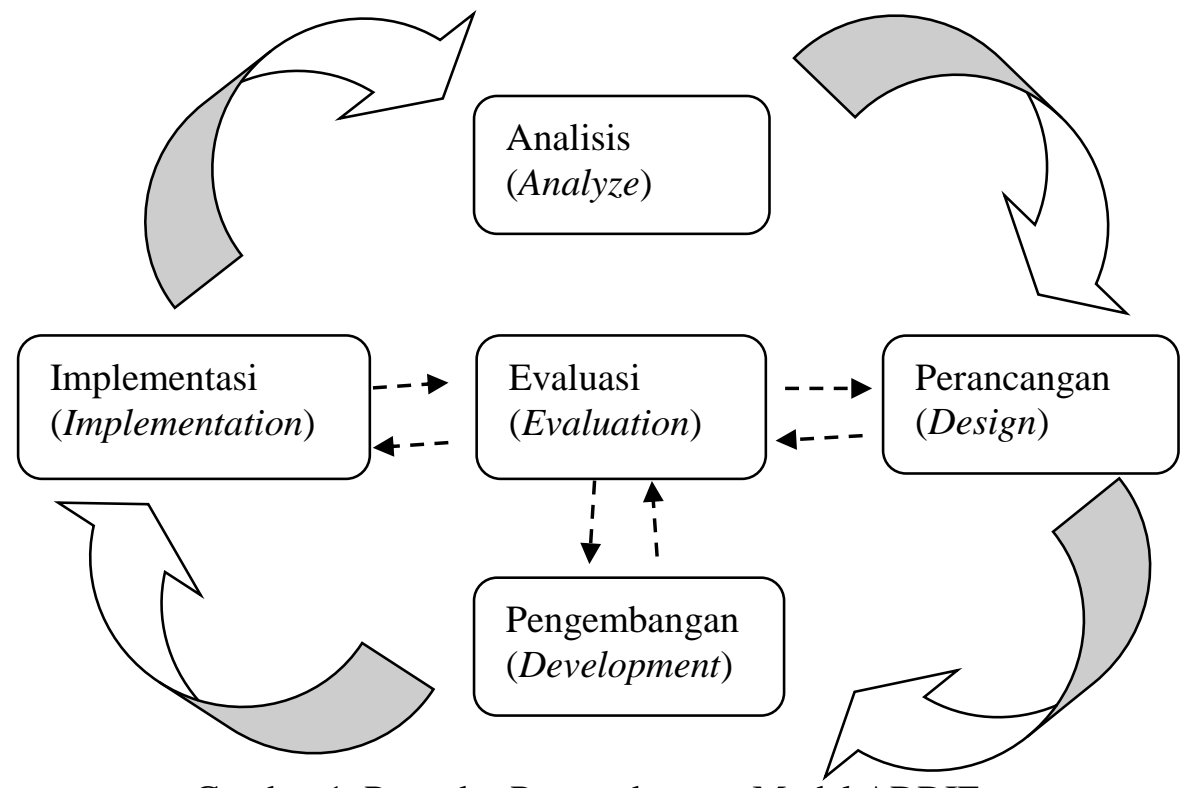

Gambar 1. Prosedur Pengembangan Model ADDIE 
Formatif: Jurnal Ilmiah Pendidikan MIPA

Vol. 8, No. 3, Desember 2018, pp. 233-250

p-ISSN: 2088-351X

e-ISSN: $2502-5457$

DOI: http://dx.doi.org/10.30998/formatif.v8i3.2613

\section{Analisis (Analysis)}

Kegiatan pada tahapan ini adalah menganalisis kebutuhan terhadap media pembelajaran yang akan dikembangkan, sehingga nantinya produk yang dikembangkan sesuai dan memenuhi kebutuhan sasaran. Proses analisis yang dilakukan adalah bahan ajar seperti video pembelajaran yang sesuai dengan kompetensi yang didasarkan pada kebutuhan, kurikulum, dan mahasiswa sebagai sasaran.

Analisis situasi dan kondisi dilakukan dengan survei awal di Universitas Islam Negeri Raden Intan Lampung Pendidikan Matematika. Kampus tersebut dipilih dengan harapan keterlaksanaan penggunaan video pembelajaran ini dapat digunakan dengan baik oleh mahasiswa. Penelitian awal dilakukan dengan cara wawancara dengan dosen matematika di kampus tersebut. Kegiatan tersebut bertujuan untuk mengetahui permasalahan-permasalahan yang terjadi di kampus berkaitan dengan proses pembelajaran matematika, yang meliputi: a) Analisis kebutuhan, b) Analisis kurikulum, dan c) Analisis karakteristik mahasiswa.

\section{Tahap Perencanaan (Design)}

Pada tahapan perencanaan peneliti akan merancang video pembelajaran yang disesuaikan dengan hasil dari tahapan analisis secara konseptual. Kegiatan dalam perancangan video pembelajaran antara lain: a) Penyusunan peta kebutuhan video pembelajaran yang memuat gambaran keseluruhan isi materi berdasarkan kompetensi pada kurikulum yang digunakan, b) Penentuan kerangka video pembelajaran yang meliputi penyusunan garis besar video, sistematika penyusunan materi akan digunakan dalam pengembangan produk, c) Penentuan desain tampilan video pembelajaran, d) Pengumpulan referensi yang berkaitan dengan materi yang akan dikembangkan dalam video pembelajaran, dan e) Penyusunan instrumen yang akan digunakan dalam penelitian.

\section{Tahapan Pengembangan (Development)}

Pada tahapan ini peneliti mengonkretkan hasil perencanaan pada tahapan desain. Rancangan produk yang telah dikonsep kemudian dikembangkan dengan melalui langkah-langkah sebagai berikut.

a. Pembuatan video

Pembuatan video disesuaikan dengan kerangka video pembelajaran yang disesuaikan dengan kebutuhan penelitian dengan memperhatikan spesifikasi sebagai berikut:

1) Berbentuk video pembelajaran yang terdiri atas pembukaan, halaman judul, sub-bab materi, contoh soal, latihan soal, kesimpulan, penutup.

2) Ditampilkan dengan layout (tampilan) sesuai dengan desain tampilan video yang telah ditentukan pada tahap desain. Selama proses penyusunan modul dosen pembimbing memberikan masukan-masukan, sehingga akhirnya video tersebut dinyatakan siap untuk divalidasi oleh ahli materi dan ahli media.

b. Memvalidasikan video pembelajaran kepada ahli materi dan ahli media. Video pembelajaran harus dinyatakan valid dan layak oleh ahli-ahli tersebut sebelum diimplementasikan dalam pembelajaran. Data hasil evaluasi dari masing-masing ahli selanjutnya dianalisis untuk mengetahui tingkat kevalidan video pembelajaran.

c. Revisi Berdasarkan hasil penyuntingan, peneliti melakukan revisi sesuai kekurangan video pembelajaran. Setelah video pembelajaran dinyatakan layak, selanjutnya dilakukan proses pengolahan naskah atau produksi.

4. Implementasi (Implementation)

Setelah video dinyatakan valid dan layak, maka video pembelajaran ini diimplementasikan dalam kegiatan pembelajaran di Kampus. Uji coba ini dilakukan 
Formatif: Jurnal Ilmiah Pendidikan MIPA

Vol. 8, No. 3, Desember 2018, pp. 233-250

p-ISSN: 2088-351X

e-ISSN: 2502-5457

DOI: http://dx.doi.org/10.30998/formatif.v8i3.2613

dengan cara mahasiswa menggunakan video pembelajaran tersebut untuk mempelajari materi program linear (penugasan). Kemudian dilanjutkan dengan pengisian angket oleh mahasiswa yang telah menggunakan video pembelajaran tersebut. Hal ini bertujuan untuk mendapatkan beberapa respons yang meliputi kepraktisan dan keefektifan video pembelajaran. Hasil tersebut sebagai bahan yang dijadikan acuan revisi sehingga video pembelajaran menjadi lebih baik.

\section{Evaluasi (Evaluation)}

Berdasarkan tahapan implementasi, video pembelajaran perlu dievaluasi.Evaluasi diperoleh dari hasil angket mahasiswa dan dosen, wawancara dosen, dan catatan lapangan. Pada tahap evaluasi dilakukan revisi akhir terhadap produk yang dikembangkan berdasarkan masukan mahasiswa yang diberikan selama tahap implementasi, karena mungkin masih terdapat kekurangan-kekurangan pada video pembelajaran matematika tersebut. Berdasarkan keseluruhan proses, maka video pembelajaran yang dikembangkan diharapkan layak digunakan untuk pembelajaran matematika karena telah memenuhi aspek kualitas yang ditinjau dari segi kesesuaian materi dengan SK KD, keakuratan materi, mendorong keingintahuan, teknik penyajian, penyajian materi, koherensi dan keruntutan alur pikir, kontekstual. Bagian metode harus dapat menjelaskan metode penelitian yang digunakan, termasuk bagaimana prosedur pelaksanaannya. Alat, bahan, media atau isntrumen penelitian harus dijelaskan dengan baik. Apabila ada rumus statistika yang digunakan sebagai bagian dari metode penelitian, sebaiknya tidak menuliskan rumus yang sudah berlaku umum.

\section{HASIL DAN PEMBAHASAN}

\section{Hasil}

Penelitian tentang pengembangan video pembelajaran matematika yang telah dilakukan memberikan pengalaman yang sangat berharga bagi peneliti sebagai mahasiswa Jurusan Pendidikan Matematika.Salah satu kegiatan peneliti adalah observasi yang bertujuan untuk menentukan kebutuhan mahasiswa, karakteristik mahasiswa terhadap mata pelajaran matematika, metode yang sering digunakan dalam pembelajaran, ketersediaan media pembelajaran.

Hasil pengembangan yang dilakukan oleh peneliti ini adalah menghasilkan video pembelajaran berbantuan Sparkol Video Scribe. Penelitian dan pengembangan ini dilakukan dengan menggunakan prosedur pengembangan Addie yang dilakukan dari tahap 1 hingga tahap 5. Data hasil setiap tahapan prosedur penelitian dan pengembangan yang dilakukan adalah sebagai berikut:

\section{Analyze (Tahap Analisis)}

Hasil analisis yang telah dilakukan digunakan sebagai pedoman dan pertimbangan dalam penyusunan matematika. Analisis yang dilakukan meliputi analisis kebutuhan, analisis kurikulum dam analisis karakteristik mahasiswa.

a. Analisis Kebutuhan

Keberadaan media pembelajaran adalah sangat dibutuhkan guna mengatasi permasalahan yang terjadi di kampus terutama pada proses pembelajaran matematika. Seperti yang terjadi ditingkat perkuliahan, masih diperlukan media pembelajaran yang mampu mendukung kegiatan belajar mandiri mahasiswa. Pengembangan media pembelajaran tersebut juga diorientasikan kepada kemajuan 
teknologi di era sekarang karena disisi lain media yang digunakan sampai saat ini masih tergolong media pembelajaran lama seperti modul cetak. Sehingga peneliti merasa sangat dibutuhkannya media pembelajaran yaitu berupa video pembelajaran untuk menunjang kegitan pembelajaran pada era sekarang.

b. Analisis Kurikulum

Kurikulum yang akan digunakan untuk pembuatan media ini yaitu Kurikulum 2013 yang akan membahas materi penugasan (program linear). Materi penugasan dipilih dalam pengembangan media pembelajaran karena merupakan salah satu materi yang sulit. Oleh karena itu, dibutuhkan media pembelajaran yang dapat mempermudah mahasiswa dalam mempelajari materi penugasan (program linear).

c. Analisis Karakteristik Mahasiswa

Dari hasil wawancara kepada dosen pada mata kuliah program linear, karakteristik mahasiswa dapat disimpulkan bahwa: 1) Kurangnya antusiasme mahasiswa sehingga menganggap matematika sebagai mata pelajaran yang tidak penting, 2) Rendahnya kemampuan mahasiswa untuk memahami konsep program linear, dan 3) Mahasiswa tidak memiliki semangat belajar dikarenakan dosen dalam memberikan materi hanya sebatas mejelaskan. Hal itu dapat diketahui saat dosen menjelaskan materi, beberapa mahasiswa ada yang berbincang dengan teman lainnya.

Berdasarkan analisis kebutuhan, analisis kurikulum, dan analisis karakteristik siswa, maka peneliti akan mengembangkanmedia pembelajaran berbatuan Sparkol Video Scribe pada materi penugasan (program linear). Video tersebut dibuat untuk mengatasi permasalahan yang ada dan bertujuan untuk meminimalisasi asumsi-asumsi mahasiswa dan agar mahasiswa dapat belajar secara mandiri dengan adanya media pembelajaran berbasis video tersebut dengan menggunakan aplikasi Sparkol Video Scribe yang diharapkan dapat disajikan atau ditampilkan lebih menarik dan menyenangkan untuk digunakan oleh mahasiswa. Diperkuat pendapat Pinahayu (2017: 25) bahwa Penggunaan media pembelajaran secara efektif dalam pembelajaran, dapat membantu menumbuhkan sikap positif dan kreativitas peserta didik. Dengan meningkatnya sikap positif dan kreativitas, akan berpengaruh pula pada meningkatnya prestasi belajar peserta didik.

\section{Design (Tahap Perancangan)}

Setelah dilakukan analisis langkah selanjutnya adalah tahapan desain. Tahapan yang dilakukan dalam tahap design produk pengembangan media pembelajaran Sparkol Video Scribe yaitu:

a. Penyusunan Desain Video

Media pembelajaran video dibuat dengan menggunakan aplikasi Sparkol Video Scribe menggunakan Frame 1024 x 768, huruf Comic Sans MS, skala spasi 1.5. Penyusunan desain video yaitu dimulai dengan membuat pembukaan awal, judul materi beserta sub-babnya, standar kompetensi, kompetensi dasar, materi , latihan soal, kesimpulan, penutup. Pada kegiatan pembelajaran pada video pembelajaran terdiri dari penjelasan materi,latihan soal. Disetiap layer pada video akan diberikan audio musik dan penjelasan dari setiap materisehingga mahasiswa dapat mendengarkan penjelasan tersebut yang diiringi audio music agar mahasiswa tidak merasa bosan pada waktu pembelajaran, pada video tersebut terdapat fitur gambargambar yang terdapat didunia nyata.

b. Perancangan Instrumen

Instrumen yang digunakan berupa angket (kuesioner) yang disusun untuk mengevaluasi media yang telah dibuat. Penyusunan instrumen dilakukan berdasarkan aspek-aspek yang disesuaikan dengan tujuan masing-masing angket. Instrumen tersebut diantaranya angket evaluasi oleh ahli media, ahli materi. Angket 
Formatif: Jurnal Ilmiah Pendidikan MIPA

Vol. 8, No. 3, Desember 2018, pp. 233-250

p-ISSN: 2088-351X

e-ISSN: 2502-5457

DOI: http://dx.doi.org/10.30998/formatif.v8i3.2613

tersebut diberikan kepada para ahli ketika mereview media sebelum diujicobakan di lapangan. Sedangkan angket setelah uji coba diberikan kepada mahasiswa berupa angket respon terhadap media.

Instrumen penilaian kualitas produk yang telah dikembangkan berupa angket daftar isian (check list) untuk ahli materi, ahli media, serta mahasiswa. Perancangan instrumen penilain diawali dengan penyusunan kisi-kisi angket dan selanjutnya disusun angket penilaian yang akan diberikan kepada para ahli untuk mengetahui kualitas produk. Serta angket untuk mahasiswa untuk mengetahui respon mahasiswa terhadap media yang telah dikembangkan.

3. Development (Tahap Pengembangan)

Pada tahap ini media mulai dibuat berdasarkan rancangan pembuatan pada tahap design. Kegiatan yang dilakukan pada tahap ini adalah sebagai berikut.

a. Pembuatan video

Pada tahap pembuatan video ini, garis besar isi video dikembangkan menjadi sebuah media pembelajaran berbentuk video. Video yang dikembangkan memiliki komponen yang bertujuan untuk membantu dan memudahkan mahasiswa dalam proses pembelajaran matematika secara mandiri pada materi penugasan. Video pembelajaran yang dibuat berbantuan Sparkol Video Scribe dikembangan menjadi video dengan rancangan sebagai berikut:

1) Pembuka Video.

Halaman pembuka terdiri dari angka hitung mundur dari 10 sampai 1, ucapan salam, judul materi, dan sub-bab. Gambar dan background yang dipilih disesuaikan dengan warna yang menarik. Tata letak gambar dan warna disesuaikan sedemikian rupa agar tampak menarik perhatian mahasiswa sehingga dengan melihat pembuka yang baik akan memotivasi mahasiswa untuk mempelajari video pembelajaran ini. Berikut ini adalah tampilan pembuka dari video pembelajaran penugasanyang telah didesain.

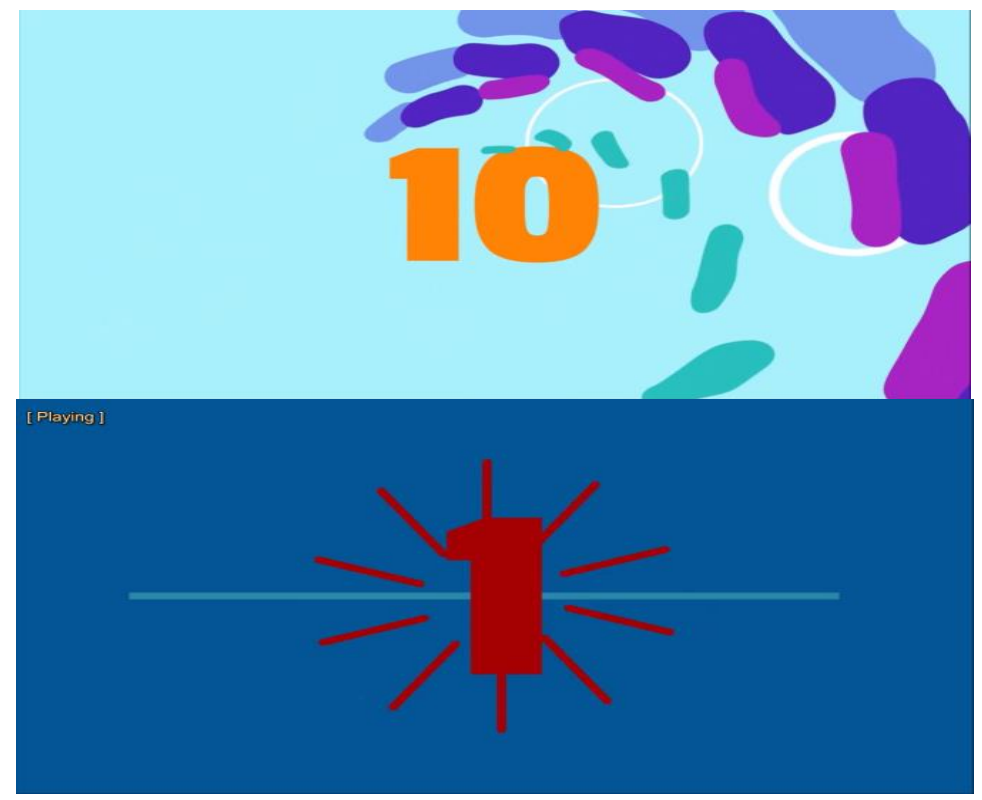

Gambar 2. Tampilan angka hitung mundur 


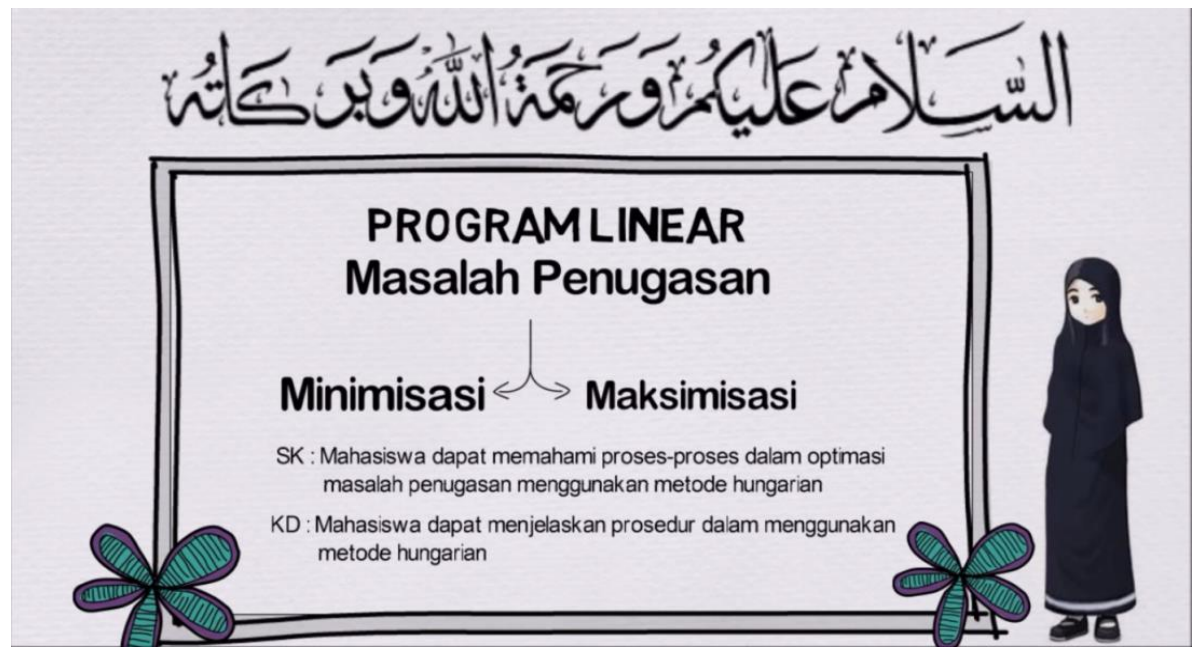

Gambar 3. Tampilan pembuka pada video pembelajaran

2) Kegiatan Belajar

Dalam video ini, materi yang disampaikan disusun secara jelas. Pemisahan materi dilakukan dalam beberapa kegiatan dengan backround yang berbeda. Hal tersebut bertujuan agar materi yang disampaikan dapat dipelajari dengan mudah dan urut. Setiap kegiatan belajar memiliki beberapa komponen antara lain uraian materi, contoh soal, dan latihan. Adapun keterangan setiap komponen tersebut adalah sebagai berikut:

a) Uraian materi

Uraian materi berisi penjelasan mengenai materi yang akan dipelajari. Berikut ini adalah salah satu contoh uraian materi yang terdapat dalam video.

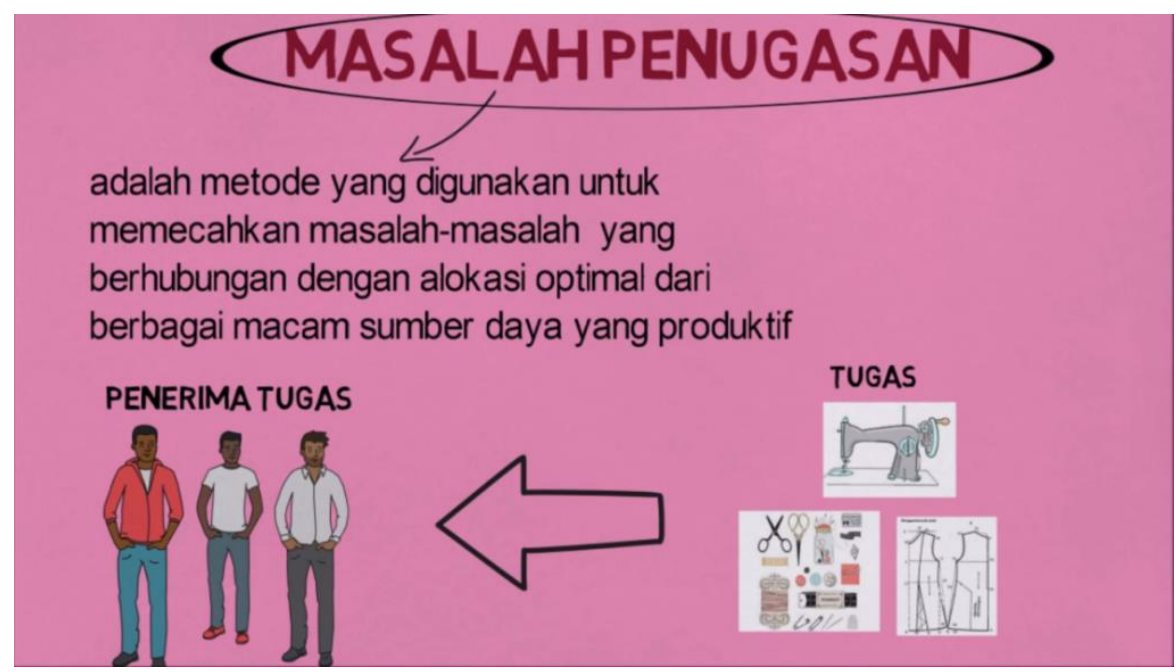

Gambar 4. Tampilan uraian materi

b) Contoh soal

Contoh soal berisi contoh soal dan penyelesaian dari materi yang telah dipelajari. Berikut ini adalah salah satu contoh soal yang terdapat dalam video. 
Formatif: Jurnal Ilmiah Pendidikan MIPA

Vol. 8, No. 3, Desember 2018, pp. 233-250

p-ISSN: 2088-351X

e-ISSN: 2502-5457

DOI: http://dx.doi.org/10.30998/formatif.v8i3.2613

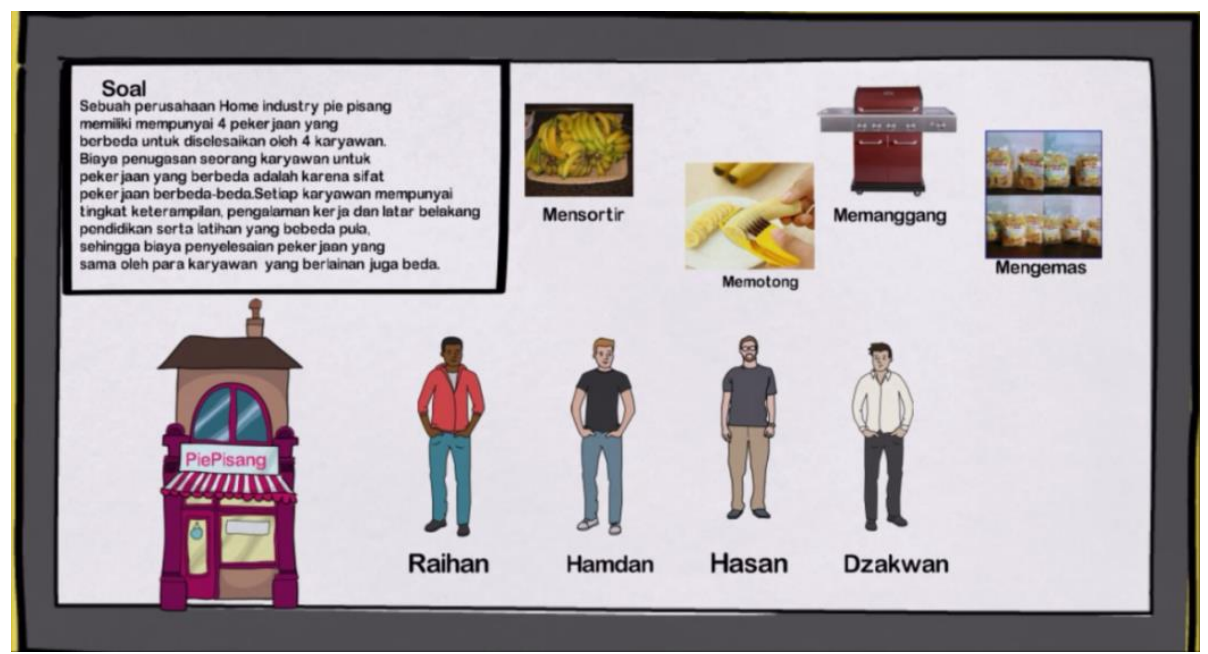

Gambar 5. Tampilan Contoh Soal

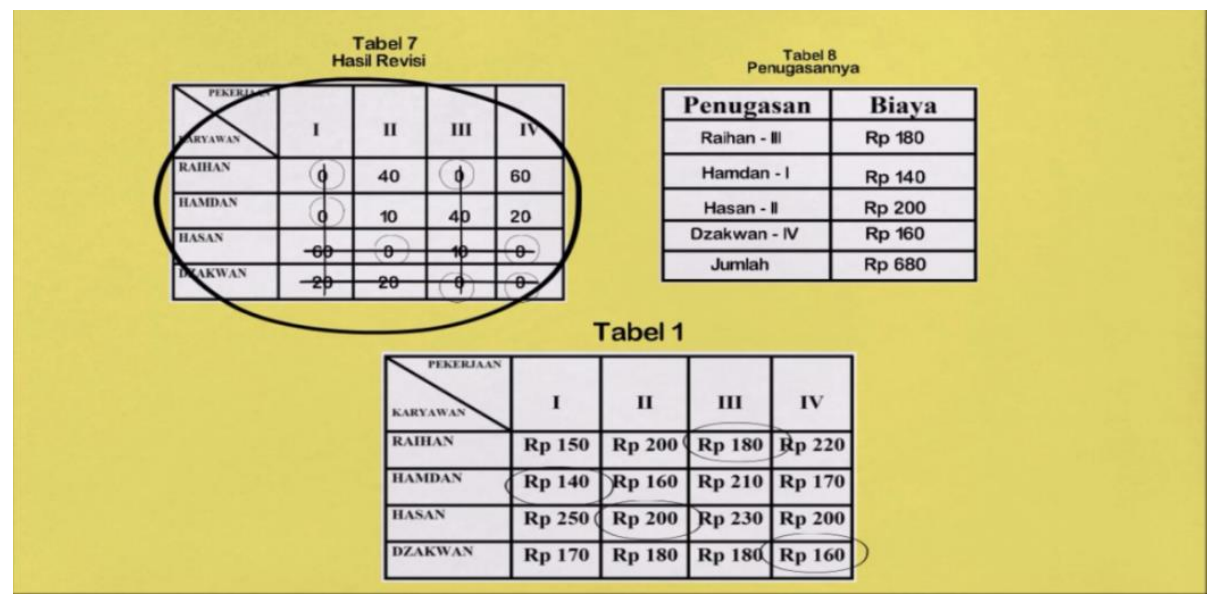

Gambar 6. Tampilan dari hasil contoh soal

c) Latihan

Setiap kegiatan belajar dilengkapi dengan soal latihan. Soal latihan dimaksudkan untuk menguji pengetahuan mahasiswa tentang materi yang telah dipelajari. Soal latihan yang disajikan berbentuk soal uraian. Soal-soal yang diberikan juga dikaitkan dengan konsep materi yang telah dipelajari mahasiswa. Berikut ini adalah salah satu contoh latihan yang terdapat dalam video. 
Formatif: Jurnal Ilmiah Pendidikan MIPA

Vol. 8, No. 3, Desember 2018, pp. 233-250

p-ISSN: 2088-351X

e-ISSN: 2502-5457

DOI: http://dx.doi.org/10.30998/formatif.v8i3.2613

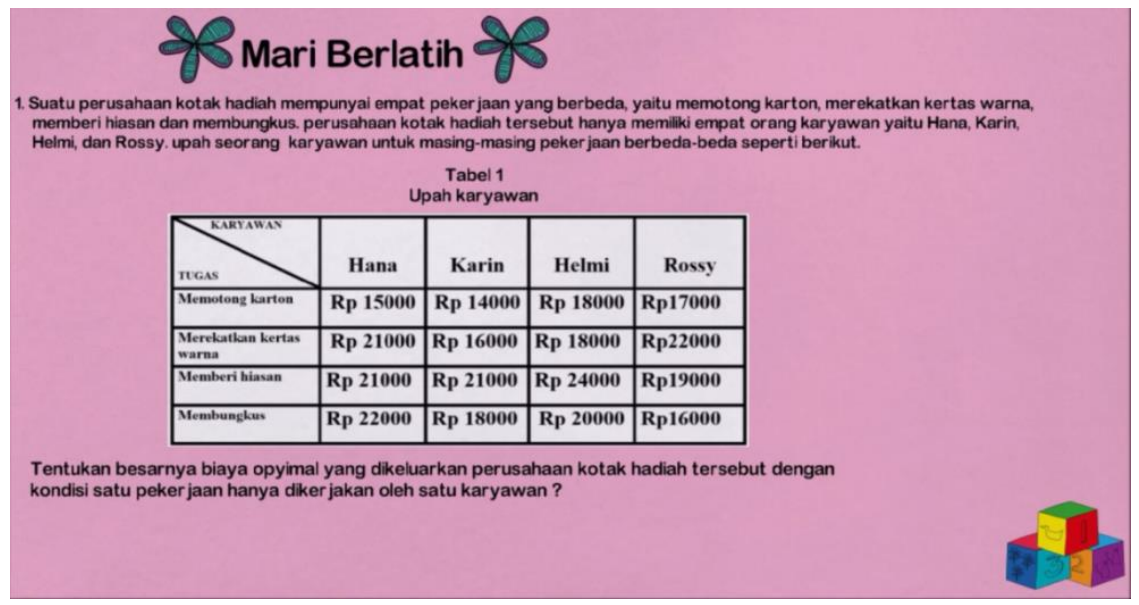

Gambar 7. Tampilan latihan

d) Kesimpulan

Bagian kesimpulan bertujuan agar mahasiswa mengetahui kesimpulan dari masingmasing sub-bab materi yang telah disampaikan dalam video tersebut.

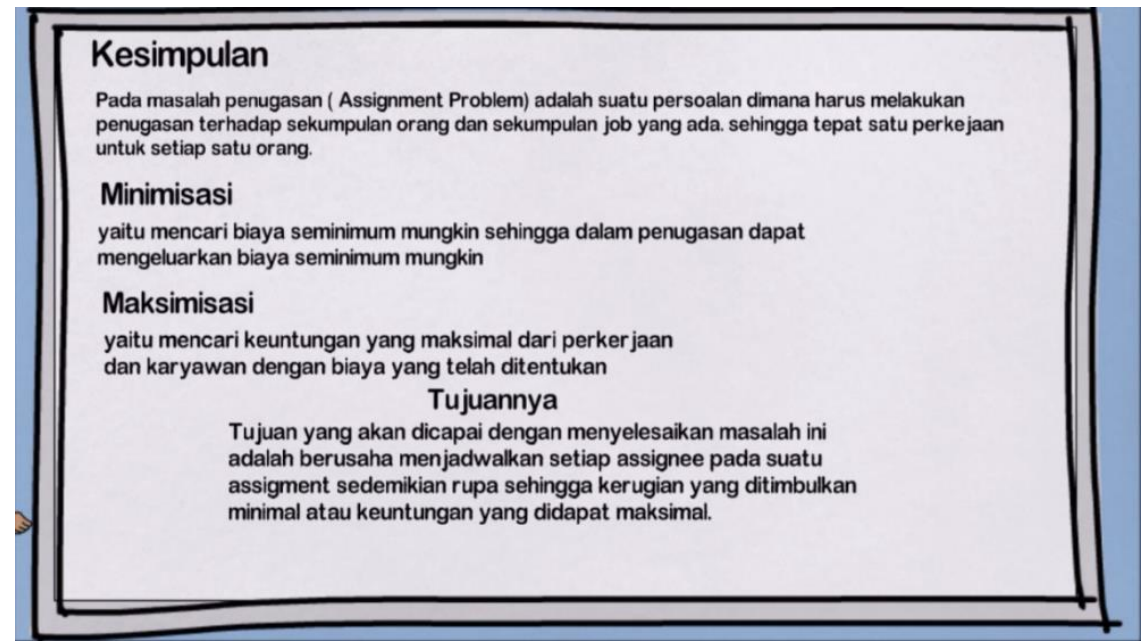

Gambar 8. Tampilan kesimpulan

b. Validasi Produk

Validasi produk dimaksudkan untuk meminta pertimbangan ahli, yaitu ahli materi dan ahli media. Berdasarkan saran mengenai kekuarangan dan kelamahan produk yang diberikan oleh validasi ahli, diharapkan video yang akan dibuat menjadi lebih baik dan layak untuk digunakan.

Penelitian dan pengembangan media pembelajaran video yang telah selesai didesain diberikan kepada tiga validator ahli materi. Kriteria dalam penentuan subyek ahli, yaitu: (1) Berpengalaman dibidangnya, (2) Berpendidikan minimal S-2 atau sedang menempuh pendidikan S-2. Validasi dilakukan dengan cara memberikan video pembelajaran untuk dilihat dan dipresentasikan dan menyerahkan lembar validasi kepada ahli materi, lembar validasi terdiri dari 16 pertanyaan. Adapun hasil validasi ahli sebagai berikut: 
Formatif: Jurnal Ilmiah Pendidikan MIPA

Vol. 8, No. 3, Desember 2018, pp. 233-250

p-ISSN: 2088-351X

e-ISSN: 2502-5457

DOI: http://dx.doi.org/10.30998/formatif.v8i3.2613

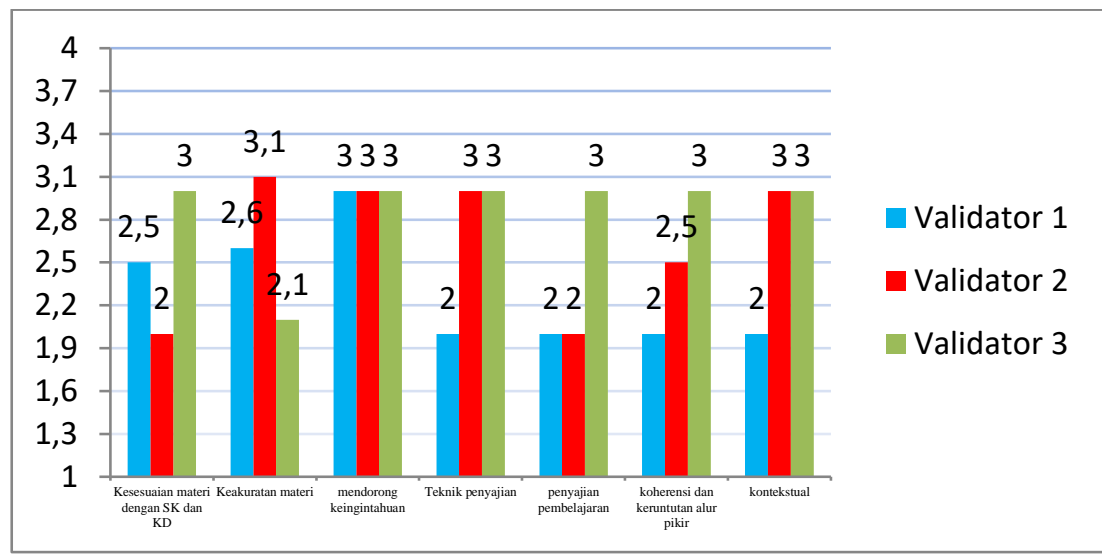

Gambar 9. Hasil validator ahli materi tahap 1

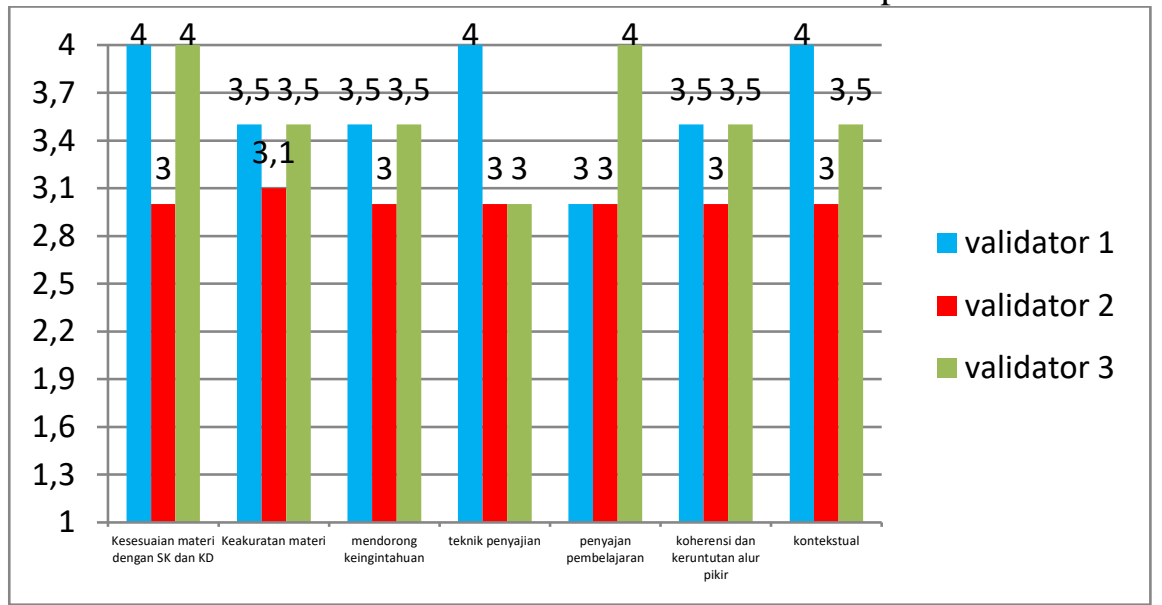

Gambar 10. Hasil validator ahli materi tahap 2

Hasil penilaian validasi ahli materi tahap 1 mengalami peningkatan pada validasi ahli materi tahap 2. Adapun nilai untuk aspek kesesuaian materi dengan SK KD pada tahap 1 diperoleh rata-rata skor sebesar 2,5 dengan kriteria "kurang valid", tahap 2 ratarata skor sebesar 3,6 dengan kriteria "valid". Pada aspek keakuratan materi, tahap 1 diperoleh rata-rata sebesar 2,6 dengan kriteria "cukup valid" dan tahap 2 diperoleh ratarata skor sebesar 3,3 dengan kriteria "valid". Pada aspek penilaian mendorong keingintahuan, tahap 1 diperoleh rata-rata skor sebesar 3 dengan kriteria "cukup valid" dan tahap 2 diperoleh rata-rata skor sebesar 3,3 dengan kriteria "valid". Pada aspek penilaian teknik penyajian, tahap 1 diperoleh rata-rata skor sebesar 2,6 dengan kriteria "cukup valid" dan tahap 2 diperoleh rata-rata skor sebesar 3,3 dengan kriteria "valid". Pada aspek penilaian penyajian pembelajaran, tahap 1 diperoleh rata-rata skor sebesar 2,3 dengan kriteria "kurang valid" dan tahap 2 diperoleh rata-rata skor sebesar 3,3 dengan kriteria "valid". Pada aspek penilaian koherensi dan keruntutan alur pikir, tahap 1 diperoleh rata-rata skor sebesar 2,5 dengan kriteria "kurang valid" dan tahap 2 diperoleh rata-rata skor sebesar 3,3 dengan kriteria "valid". Pada aspek penilaian kontekstual pada tahap 1 diperoleh rata-rata skor sebesar 2,6 dengan kriteria "cukup valid" dan tahap 2 diperoleh rata-rata skor sebesar 3,5 dengan kriteria "valid". Perbandingan hasil validasi ahli materi pada tahap 1 dan tahap 2 dapat dilihat juga melalui gambar 11 berikut ini: 
Formatif: Jurnal Ilmiah Pendidikan MIPA

Vol. 8, No. 3, Desember 2018, pp. 233-250

p-ISSN: 2088-351X

e-ISSN: 2502-5457

DOI: http://dx.doi.org/10.30998/formatif.v8i3.2613

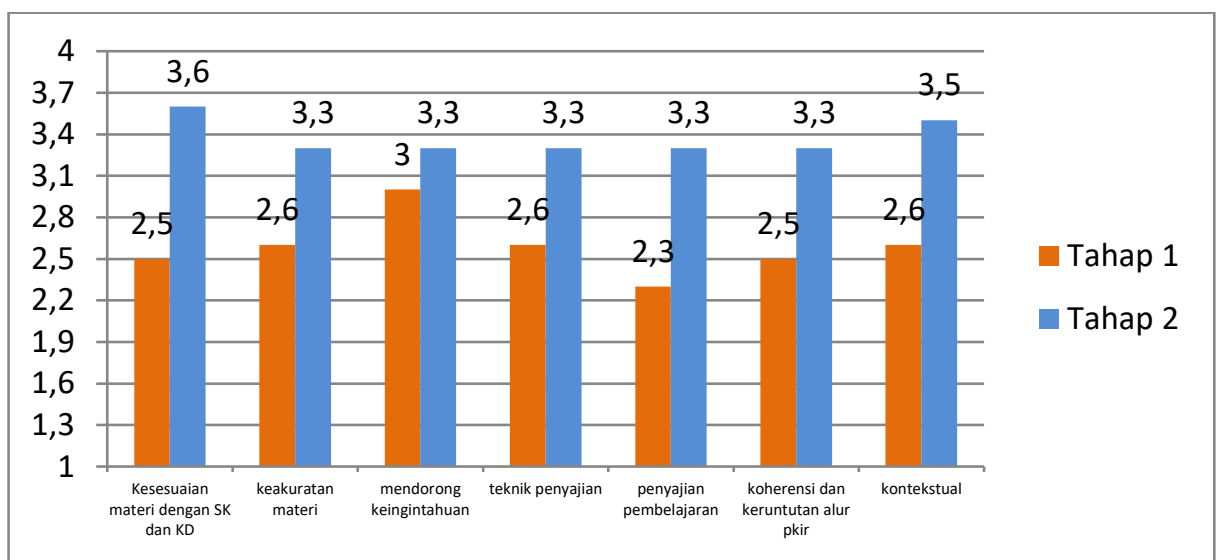

Gambar 11. Grafik perbandingan tahap 1 dan tahap 2

Dari gambar grafik terlihat bahwa terjadi peningkatan yang sangat signifikan dari tahap 1 ke tahap 2, baik pada aspek kesesuaian materi dengan SK KD, keakuratan materi, mendorong keingintahuan, teknik penyajian, penyajian pembelajaran, koherensi dan keruntutan alur pikir, maupun kontekstual.

Penelitian dan pengembangan media pembelajaran video yang telah selesai didesain diberikan kepada tiga validator ahli media. Kriteria dalam penentuan subyek ahli, yaitu: (1) Berpengalaman di bidangnya, (2) Berpendidikan minimal S-2 atau sedang menempuh pendidikan S-2. Validasi dilakukan dengan cara memberikan video pembelajaran untuk dilihat dan dipresentasikan dan menyerahkan lembar validasi kepada ahli media, lembar validasi terdiri dari 13 pertanyaan. Adapun hasil validasi ahli sebagai berikut:

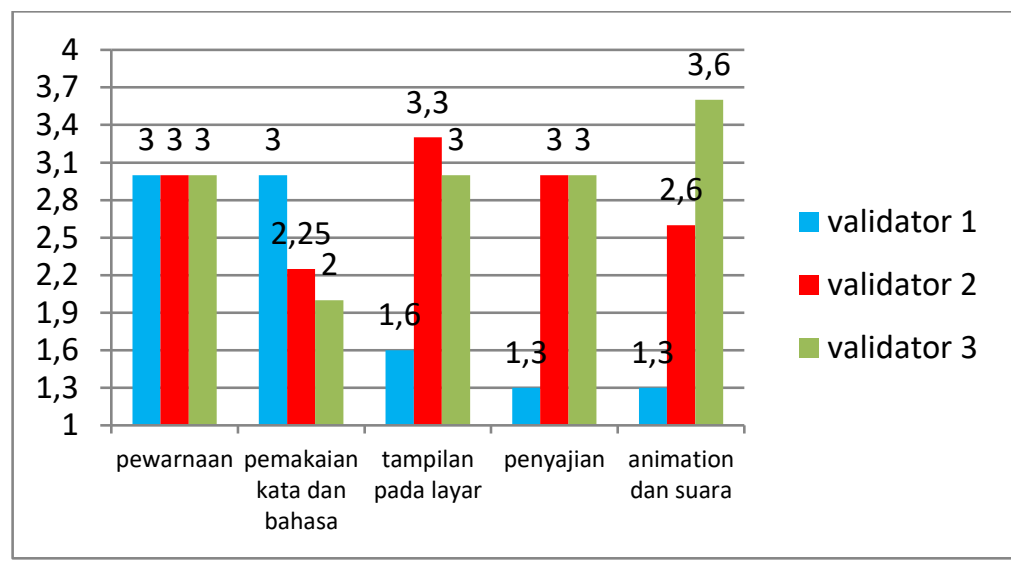

Gambar 12. Hasil validasi media tahap 1 
Formatif: Jurnal Ilmiah Pendidikan MIPA

Vol. 8, No. 3, Desember 2018, pp. 233-250

p-ISSN: 2088-351X

e-ISSN: 2502-5457

DOI: http://dx.doi.org/10.30998/formatif.v8i3.2613

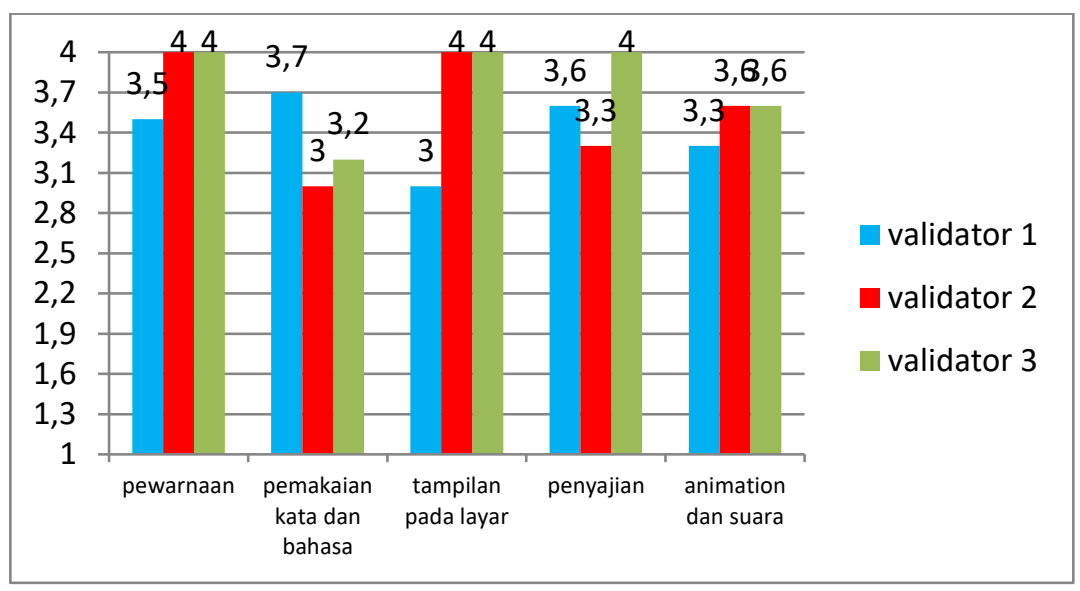

Gambar 13. Hasil validasi media tahap 2

Terlihat dari gambar 13 hasil validasi ahli media pada tahap 2 nilai rata-rata dari semua aspek mengalami peningkatan yang cukup baik dan sudah masuk dalam kriteria valid maka video pembelajaran sudah layak dan tidak dilakukan perbaikan kembali. Hasil penilaian validasi ahli media tahap 1 mengalami peningkatan pada validasi ahli media tahap 2. Adapun nilai untuk aspek pewarnaan pada tahap 1 diperoleh rata-rata skor 3,0 dengan kriteria "cukup valid" dan pada tahap 2 rata-rata skor sebesar 3,8 dengan kriteria "valid". Rata-rata skor pada aspek pemakaian kata dan bahasa pada tahap 1 sebesar 3,0 dengan kriteria "cukup valid" sedangkan pada tahap 2 rata-rata skor sebesar 3,3 dengan kriteria "valid". Rata-rata skor pada aspek tampilan layar tahap 1 sebesar 2,6 dengan kriteria "cukup valid" sedangkan pada tahap 2 rata-rata skor sebesar 3,6 dengan kriteria "valid". Selanjutnya, rata-rata skor pada aspek penyajian tahap 1 sebesar 2,4 dengan kriteria "kurang valid" dan pada tahap 2 rata-rata skor sebesar 3,6 dengan kriteria "valid". Kemudian rata-rata skor pada aspek animation dan suara di tahap 1 sebesar 2,56 dengan kriteria "cukup valid" dan pada tahap 2 rata-rata skor sebesar 3,5 dengan kriteria "valid". Perbandingan hasil validasi ahli media pada tahap 1 dan tahap 2 dapat dilihat juga melalui gambar 14 berikut ini:

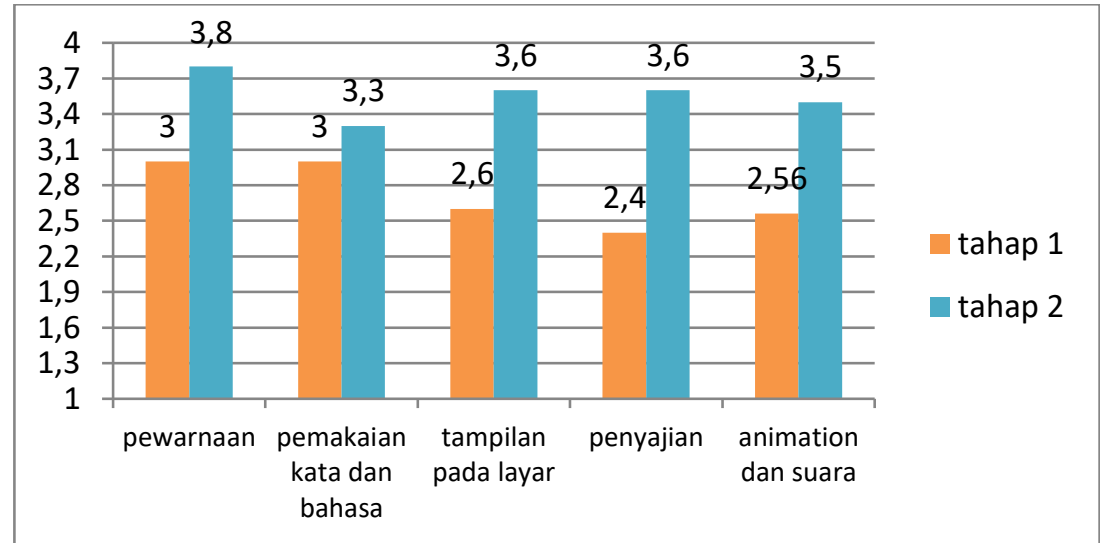

Gambar 14. Grafik Perbandingan Hasil Validasi Ahli Media Tahap 1 dan Tahap 2 
Formatif: Jurnal Ilmiah Pendidikan MIPA

Vol. 8, No. 3, Desember 2018, pp. 233-250

p-ISSN: 2088-351X

e-ISSN: 2502-5457

DOI: http://dx.doi.org/10.30998/formatif.v8i3.2613

Berdasarkan gambar 14, grafik perbandingan hasil validasi ahli media menunjukkan peningkatan dari tahap 1 ke tahap 2, baik pada aspek pewarnaan, pemakaian kata dan bahasa, tampilan pada layar, penyajian, maupun animation dan suara.

\section{Implementation (Tahap Implementasi)}

Setelah produk melalui tahap validasi oleh para ahli serta telah diperbaiki, selanjutnya produk diujicobakan kepada mahasiswa di Kampus Universitas Islam Negri Raden Intan Lampung. Dengan uji coba yang terdiri dari 10 mahasiswa untuk uji kelas kecil dan 20 mahasiswa untuk uji kelas besar. Uji coba ini bertujuan untuk menguji kemenarikan dari produk video pembelajaran yang dikembangkan.

Hasil uji coba kelas besar diperoleh rata-rata 3,35 dengan kriteria interpretasi yang dicapai yaitu "Sangat Menarik". Hal ini berarti video pembelajaran yang dikembangkan oleh peneliti juga mempunyai kriteria menarik untuk digunakan sebagai media belajar mahasiswa pada materi penugasan untuk mahasiswa di Jurusan Pendidikan Matematika Universitas Islam Negeri Raden Intan Lampung.

\section{Pembahasan}

Pada pengembangan video pembelajaran ini, peneliti menggunakan model pengembangan ADDIE yang terdiri dari lima tahapan yaitu: analysis, design, development, implementation, evaluation. Berdasarkan permasalahan pada tahap analisis yang telah dikemukakan dalam hasil prapenelitian diketahui bahwa dalam proses pembelajaran di kelas dosen masih menggunakan metode ceramah serta belum adanya pembaruan media pembelajaran bagi mahasiswa. Selain itu juga masih rendahnya kemampuan mahasiswa dalam memahami konsep penugasan. Oleh karena itu, dibutuhkan media pembelajaran yang dapat mempermudah mahasiswa dalam mempelajari materi penugasan tersebut, sehingga dipilihlah video pembelajaran berbantuan Sparkol Video Scribe untuk digunakan sebagai media pembelajaran mahasiswa.

Setelah tahap analisis, tahap selanjutnya adalah tahap design (perancangan). Pada tahap perancangan dilakukan penyusunan dalam pembuatan video dan perancangan instrumen. Penyusunan desain dilakukan agar peneliti secara garis besar dapat mengetahui bagaimana video pembelajaran akan dibuat. Penyusunan yaitu dengan menyusun pembukaan awal, judul materi beserta sub-babnya, standar kompetensi, kompetensi dasar, materi, latihan soal, kesimpulan, penutup. Pada kegiatan pembelajaran video pembelajaran terdiri dari penjelasan materi dan latihan soal. Sedangkan perancangan instrumen dimaksudkan untuk menyusun angket untuk mengevaluasi media yang telah dibuat. Instrumen tersebut di antaranya adalah angket ahli media dan ahli materi serta angket respons mahasiswa terhadap pengunaan media.

Selanjutnya ialah tahap development. Tahap development merupakan tahap dalam pembuatan video pembelajaran yang akan digunakan dalam proses belajar. Setelah produk selesai dibuat, kemudian dilakukan evaluasi oleh para ahli yang disebut dengan validasi. Tujuannya untuk memperoleh masukan-masukan guna perbaikan media yang dikembangkan. Masukan dari para ahli sebagai acuan revisi, selain itu juga pengisian angket validasi akan menentukan kelayakan media untuk dapat diujicobakan kepada mahasiswa. Revisi ini dilakukan sebagai langkah membuat produk yang layak digunakan bagi mahasiswa.

Hasil dari penilaian ahli materi terhadap video pembelajaran ini termasuk dalam kategori "Valid" dengan nilai rata-rata sebesar 3,37 dan penilaian ahli media terhadap media pembelajaran ini juga termasuk dalam kategori "Valid" dengan nilai rata-rata 
sebesar 3,56. Setelah media direvisi dan dinyatakan "Valid" untuk diujicobakan, kemudian dilakukan uji coba kepada mahasiswa. Tahap ini disebut dengan tahap implementation. Berdasarkan hasil olah data dari angket respons mahasiswa pada uji coba yang diikuti oleh 10 mahasiswa dan diikuti oleh 20 mahasiswa dalam uji coba kelas besar terhadap video pembelajaran yang dikembangkan menghasilkan video pembelajaran dalam kriteria interpretasi "sangat menarik" dengan hasil rata-rata skor yaitu3,55.

Tahap terkhir yaitu mengevaluasi dari pengunaan video pembelajaran atau bisa disebut tahap evaluation. Berdasarkan hasil yang telah diperoleh pada tahap implementasi terhadap video yang telah diujicobakan dapat disimpulkan kualitas media pembelajaran yaitu video sudah mencerminkan media pembelajaran yang menarik sebagai sumber media belajar mahasiswa sehingga video pembelajaran layak untuk digunakan dalam proses pembelajaran. Seperti penelitian yang dilakukan Erlia Dwi Pratiwi dengan metode penelitian Research and Devolopment yang bertujuan untuk melihat pengembangan media pembelajaran dan melihat kelayakan dari media yang dikembangkan tersebut. Hasil penelitian ini adalah menghasilkan produk berupa media pembelajaran Fisika berbasis Sparkol Video Scribe pokok bahasan kinematika gerak diperguruan tinggi mengetahui kelayakan dari kualitas produk yang telah dikembangkan adalah sangat layak dengan pesentasi $86,70 \%$ berdasarkan penelitian ahli media dan $84,26 \%$ oleh ahli materi dalam katagori sangat layak. Respons mahasiswa pada media pembelajaran Fisika berbasis Sparkol Video Scribe pokok bahasan kinemtika gerak dengan persentase 96,00\% diperguruan tinggi (Pratiwi, 2017). Selain itu juga penelitian yang dilakukan oleh Dilla Oktaviningrum dengan tujuan menguji keefektifan belajar pada materi perkantoran pada tingkat perguruan tinggi. Aspek keefektifan belajar melalui media yang dikembangkan dinyatakan berhasil dengan nilai rata-rata kelas eksperimen $88,00 \%$ lebih tinggi daripada kelas kontrol yaitu 74,93\% (Octavianingrum, 2016).

Penelitian MariaYasinta Menge Making dengan tujuan untuk: (1) mengembangkan media pembelajaran mekanik teknik berbasis Video Scribe dan Aurora 3D Presentation pada materi konstruksi pelengkung tiga sendi, (2) mengetahui kualitas kelayakan media pembelajaran mekanik teknik berbasis Video Scribe dan Aurora 3D Presentation pada materi konstruksi pelengkung tiga sendi, (3) mengetahui ketuntasan prestasi belajar mahasiswa pada materi konstruksi pelengkung tiga sendi, dan (4) mengetahui apakah produk yang dihasilkan dapat meningkatkan minat belajar mahasiswa. Penelitian ini merupakan penelitian pengembangan yang mengacu pada model pengembangan 4D (four-D) yang meliputi empat tahapan yaitu: pendefinisian (define), perancangan (design), pengembangan (develop), dan penyebaran (disseminate). Kelayakan produk berdasarkan validasi ahli materi yaitu sebesar (88\%) termasuk kriteria "sangat layak" untuk digunakan, sedangkan berdasarkan validasi ahli media sebesar $(82,67 \%)$ termasuk kriteria "sangat layak" untuk digunakan. Hasil evaluasi I sebesar (80\%) termasuk kriteria "tinggi" (Making \& Hariyanto, 2016).

Berdasarkan penelitian yang dilakukan Erlia Dwi Pratiwi, Dilla Oktaviningrum, dan MariaYasinta Menge Making telah menujukkan keberhasilan dalam penggunaan media Sparkol Video Scribe serta membawa pengearuh dalam tingkat keberhasilan dari hasil belajar mahasiswa sehingga peneliti melakukan penelitian adalah penugasan (program linear) dengan menggunakan media Sparkol Video Scribe di Universitas Islam Negeri Raden Intan Lampung. 


\section{PENUTUP}

\section{Simpulan}

Berdasarkan penelitian dan pembahasan yang telah dipaparkan, pengembangan video pembelajaran matematika berbantuan Sparkol Video Scribe pada materi penugasan (program linear) pada tahap awal adanya analisis kebutuhan dan analisis karakteristik mahasiswa bahawasannya mahasiswa membutuhkan adanya pembahauan terhadap media pembelajaran pada materi penugasan (program linaer) ini sehingga peneliti menggunakan Sparkol Video Scribe ini sebagai alat bantu dalam pembuatan media berbentuk video. Video tersebut dibuat dengan menyesuaikan kebutuhan dan karakteristik dari mahasiswa itu sendiri. Video pembelajaran tersebut divalidasi oleh ahli materi dan ahli media dengan memperoleh kriteria valid dengan rata-rata mencapai skor 3,37 untuk validasi ahli materi dan mencapai skor 3,56 serta hasil uji coba pada uji coba kelas kecil dan uji coba kelas besar rata-rata mecapai skor 3,55 dengan kriteria sangat menarik. Sehingga dapat disimpulkan bahwa pengembangan media pembelajaran berbantuan Sparkol Video Scribe pada materi penugasan (program linear) adalah layak dan menarik untuk digunakan bagi mahasiswa.

\section{Saran}

Berdasarkan penelitian yang dilakukan, peneliti memiliki beberapa saran yaitu

1. video pembelajaran berbantuan Sparkol Video Scribe pada materi penugasan (program linear) di Universitas Islam Negeri Raden Intan Lampung ini perlu disempurnakan kembali, jika memang hal tersebut bermanfaat dan menghasilkan produk yang lebih berkualitas.

2. Perlu dikembangkan video pembelajaran berbantuan Sparkol Video Scribe pada materi yang lain yang disesuaikan dengan kebutuhan mahasiswa serta kondisi kampus masing-masing agar kegiatan pembelajaran dapat berlangsung efektif dan menyenangkan.

\section{DAFTAR PUSTAKA}

Arsyad, A. (2016). Media Pembelajaran. Jakarta: Raja Grafindo Persada.

Farida, F. (2015). Mengembangkan kemampuan pemahaman konsep peserta didik melalui pembelajaran berbasis VCD. Al-Jabar: Jurnal Pendidikan Matematika, 6(1), 25-32.

Indiyani, N. E., \& Listiara, A. (2006). Efektivitas metode pembelajaran gotong royong (cooperative learning) untuk menurunkan kecemasan siswa dalam menghadapi pelajaran matematika (suatu studi eksperimental pada siswa di SMP 26 Semarang). Jurnal Psikologi, 3(1), 10-28.

Harini, L. P. I. \& Oka, T. B. (n.d.). Penggunaan Mind Map dalam Pembuktian Matematika.

Layn, M. R. (2018). Improving mathematics learning outcomes through cooperative learning model type NHT In Grade VIII A Students MTS Muhammadiyah. Formatif: Jurnal Ilmiah Pendidikan MIPA, 8(1). https://doi.org/10.30998/formatif.v8i1.2319 
Leonard, L., \& Chaidir, M. (2018). The development of learning design on down syndrome children's numbers recognition. Formatif: Jurnal Ilmiah Pendidikan MIPA, 8(1). https://doi.org/10.30998/formatif.v8i1.2285

Making, M. Y. M., \& Hariyanto, V. L. (2016). Pengembangan media pembelajaran mekanika teknik berbasis video scribe dan aurora 3D presentation pada materi konstruksi pelengkung tiga sendi. E-Journal Pend. Teknik Sipil Dan Perencanaan, 4(1).

Nugroho, A. A., Putra, R. W. Y., Putra, F. G., \& Syazali, M. (2017). Pengembangan blog sebagai media pembelajaran matematika. Al-Jabar: Jurnal Pendidikan Matematika, 8(2), 197-204.

Octavianingrum, D. (2016). Pengembangan media audio visual sparkol Video Scribe dalam pembelajaran mengelola pertemuan/rapat di lembaga pendidikan profesi (lpp) ipmi kusuma bangsa Surakarta jurusan administrasi perkantoran ( $\mathrm{PhD}$ Thesis). UNS (Sebelas Maret University).

Pratiwi, E. D. (2017). Pengembangan Media Pembelajaran Fisika Berbasis Sparkol Video Scribe Pokok Bahasan Kinematika Gerak di Perguruan Tinggi (PhD Thesis). UIN Raden Intan Lampung.

Sari, A. W. (2017). Pengembangan MEdia Pembelajaran Berbantuan Web dengan Pendekatan Etnomatematika pada Pokok Bahasan Bangun Ruang Sisi Datar. Tesis. Tidak Dipublikasikan. UIN Raden Intan Lampung.

Setyono, Y. A., Karmin, S., \& Wahyuningsih, D. (2013). Pengembangan media pembelajaran fisika berupa buletin dalam bentuk buku saku untuk pembelajaran fisika kelas VIII materi gaya ditinjau dari minat baca siswa. Jurnal Pendidikan Fisika, l(1). 
Formatif: Jurnal Ilmiah Pendidikan MIPA

Vol. 8, No. 3, Desember 2018, pp. 233-250

p-ISSN: 2088-351X

e-ISSN: 2502-5457

DOI: http://dx.doi.org/10.30998/formatif.v8i3.2613 